\title{
DOES MANAGEMENT SUPPORT MATTER IN ELUCIDATING THE LINKAGE OF INDIVIDUAL CHARACTERISTICS AND E-LEARNING ACCEPTANCE?
}

\author{
Sutrisno Hadi Purnomo ${ }^{1 *}$ and Tur Nastiti ${ }^{2}$ \\ ${ }^{1}$ Socio Economics Laboratory, Faculty of Agriculture, \\ Universitas Sebelas Maret, Indonesia \\ ${ }^{2}$ Department of Management, Faculty of Economics and Business, \\ Universitas Gadjah Mada, Indonesia \\ *Corresponding author: sutrisnohadi@staff.uns.ac.id
}

Published online: 27 June 2019

To cite this article: Purnomo, S.H. and Nastiti, T. (2019). Does management support matter in elucidating the linkage of individual characteristics and e-learning acceptance? Asian AcademyofManagement Journal,24(1), 83-110. https://doi.org/10.21315/aamj2019.24.1.4

To link to this article: https://doi.org/10.21315/aamj2019.24.1.4

\begin{abstract}
This study attempts to examine the hypothesis that management support elucidates the relationship between individual characteristic and e-learning acceptance factors including perceived ease of use and perceived usefulness. Quantitative methodology was used in this study through survey. This study collects 306 usable questionnaires from employees of Indonesian banking industries with experience in e-learning courses. The study uses descriptive statistical data and hierarchical regression analysis. The hypotheses on individual characteristics and acceptance factors relationships were generally accepted. Management support was found to positively contribute to e-learning acceptance. Management support has also showed its importance in elucidating the relationship between tangible individual characteristics and e-learning acceptance. However, the findings show limited supports of the moderating influence of management support. Management support, in terms of consideration, policy, and facilities were valuable in developing an appropriate acceptance of e-learning application in a company. Management support shows the managers' commitment and assurance of e-learning benefits thus strengthening employees' willingness to use e-learning, especially for those who previously experienced in using technology-based devices. This study contributes new knowledge to the existing body of literature on e-learning adoption research by providing a more complex view of e-learning adoption.
\end{abstract}

Keywords: management support, individual characteristic, e-learning acceptance, moderating role, quantitative methodology

(C) Asian Academy of Management and Penerbit Universiti Sains Malaysia, 2019. This work is licensed under the terms of the Creative Commons Attribution (CC BY) (http://creativecommons. org/licenses/by/4.0/). 


\section{INTRODUCTION}

Nowadays, it is often noted that fast-moving business tends to trigger inevitable changes and pressures for those working in a particular business environment. As a result of this, learning has become imperative in order for business to maintain a competitive advantage. Thus, learning is emerging as prominent organisational strategic tool in today's world (Noh, Kim, \& Jang, 2016) that keeps business aligned with environmental changes. Consequently, a new method of learning that able to cope the changing workplace is expectantly introduced. Technology, as an important vehicle that foster information access which allows people to learn and keep up with changes in a global economy by eliminating the barriers of time and distance, has been considerately adopted by business organisations. The use of internet technology to facilitate learning, called e-learning, is having a major impact on education and training by offering virtually unlimited educational opportunities for the learners, including the ability to control and make decisions on their own, anytime or anywhere (de Alva, 2000; Hairston, 2007; Piccoli \& Ahmad, 2001). The application of e-learning in business is not only emerging in developed countries, but also in developing countries. With a special context to the developing country, e-learning application into business is beneficial in some aspects. Cutting out expenses for learning stuffs makes knowledge transfer in business much more affordable. Besides, the application also helps to eliminate logistic issues in learning activities because of poor public transport. This point of view has taken e-learning as a considerable topic for researchers with a special interest to e-learning application in a developing country, including Indonesia. As one of the fourth most populous country on earth after China, India, and the United States, 54.68\% of Indonesia's 262 million populations are internet users (Setiawan, 2017).

The role of individual characteristic in predicting e-learning acceptance has been demonstrated by numerous studies (Hussein, Aditiawarman, \& Mohamed, 2007; Jirachiefpattana, 2015; Lee, 2006; Lee, Hsieh, \& Ma, 2010; Ong \& Lai, 2006; Ong, Lay, \& Wang, 2004; Park, Roman, Lee, \& Chung, 2009). Nevertheless, there is limited empirical research examining the moderating effect of management support in the relationship between individual characteristic and e-learning acceptance factors. Although, some researchers have recently started to examine the potential moderating effects of variables such as technology among others, the moderating role of management support has remained under-researched. For instance, Sun and Zhang (2006) examined the influence of organisational, technological, and individual factors towards relationship among acceptance factors while recently, Yeh, Huang, and Yeh (2011) demonstrated the moderating effect of social role on user behaviour and virtual world usage. However, there is a general consensus 
among researchers that more extended research must be conducted to improve the current practice and knowledge of e-learning acceptance. This study attempts to join this call by interrogating the moderating role of management support in the relationship between individual characteristic and acceptance factors of e-learning.

Management support is considered to play a critical role in the successful implementation process of information systems (Dong, Neufeld, \& Higgins, 2009). Sharma and Yetton (2003) provide empirical evidence suggesting a complex relationship between management support and implementations success of information system. Other empirical studies into the implementation of information system innovations, such as e-learning, consider management support as a critical factor in successful implementation of information system (LeonardBarton \& Deschamps, 1988; Purvis, Sambamurthy, \& Zmud, 2001). Practically, Hashim (2008) points out that managers and supervisors need to play their roles in encouraging their employees to embrace self-directed learning via internet. Especially, during the early stages of learning and using a system, perceived ease of use is significantly affected by management support (Walker, 2004). Venkatesh (1999) augments that the effect of management support and perceived usefulness becomes stronger when the user gains experience over a period of time. These previous studies posit the importance to evaluate the moderating effect of management support on the relationship between individual characteristic and acceptance factors of e-learning system.

In light of this identified research void, the main purpose of this study is to examine the hypothesis that management support elucidates the relationship between individual characteristic and e-learning acceptance factors including perceived ease of use and perceived usefulness. The current study predicts a positive moderating influence of management support in the individual characteristics to perceive ease of use and perceived usefulness relationship in e-learning context. Therefore, the objectives of this study are three-fold. Firstly, the present study seeks to investigate the impact of individual characteristics and both acceptance factors (perceive ease of use and perceived usefulness). Secondly, this study examines the influence management support on perceive ease of use and perceived usefulness. Finally, this study aims to interrogate whether management support is a moderator of the relationship between individual characteristic and acceptance factors. This study is expected to contribute new knowledge to the existing body of literature on e-learning adoption research, because it provides a more complex view of e-learning adoption. Besides, the current study further suggests that future research should investigate factors to elucidate the dynamics in the relationship between individual characteristics and acceptance model. 


\section{THEORETICAL BACKGROUND}

\section{Individual Characteristic}

Individuals differ in terms of their experiences, cognitions, influences, motivations, and skills in the acceptance of information technology (Nelson, 1990). There is a correlation between individual characteristics such as computer literacy background and individual attitudes towards the perceived usefulness and the perceived ease of use of information technology (Walker, 2004). Among the characteristics they identified in the literature are prior experience, having a computer at home, and personality produce gender difference towards computers. This study identifies four factors that are expected to influence e-learning acceptance, that is, computer self-efficacy, prior experience, computer anxiety, and internet self-efficacy. Factors relate to self-efficacy represents a learner's attitude as a predisposed mental stage in an individual. It is learned and perceived based on the learner's social and personal stimuli. Anxiety factor has also been discussed in the attitude literature. However, it is noted to represents the degree of negativity. Prior experiences factor represents tangible past memorable activities influencing future behaviour through perception, awareness, and intention. Those four factors are depicted to represent the interrelated components of individual characteristics.

\section{Acceptance Factors}

In Technology Acceptance Model (TAM) as an information system theory that models how users come to accept and use a technology, the behavioural intentions of users regarding technology are affected by two variables: perceived ease of use and perceived usefulness. The former affects the latter, which means that if users feel the system is easy to use, they will feel that e-learning is useful and they will be prepared to use the technology. The causal relationship that exists between these two variables has been confirmed by a number of empirical studies (e.g., Davis, 1989; Venkatesh \& Davis, 2000).

Davis (1989) defined perceived ease of use as the degree to which a person believes that using a particular system would be free from effort. Perceived usefulness is based on the definition of the word useful which means capable of being used advantageously (Davis, 1989). Furthermore, Davis (1989) defined perceived usefulness as the degree to which a person believes that using a system would enhance his/her job performance. Perceived usefulness is the extent to which a person believes that using a technology will enhance his/her productivity and is an outcome of expectancy and a measure of extrinsic motivation (Venkatesh, 1999). 
Based on these two variables in TAM, this study focuses to examine the relationship between individual characteristic, management support, and two acceptance factors of TAM including perceived ease of use and perceived usefulness in the e-learning context.

\section{Computer Self-Efficacy and Acceptance Factors}

This study explores individual characteristics, in particular, computer self-efficacy, prior experience, computer anxiety, and internet self-efficacy. Furthermore, acceptance factors of e-learning are gauged by perceived ease of use and perceived usefulness.

Computer self-efficacy plays a critical role in terms of its effect on perceived ease of use (Grandon, Alshare, \& Kwun, 2005; Lee, Hsiao, \& Purnomo, 2014; Madorin \& Iwasiw, 1999) and perceived usefulness (Hayashi, Chen, Ryan, \& Wu, 2004; Venkatesh \& Davis, 2000) because individuals' confidence in their computer-related knowledge and abilities can influence their judgement of the ease or difficulty of carrying out a specific task using a new information technology. As to the relationship between computer self-efficacy and perceived usefulness, significant influences of computer self-efficacy on outcome expectations were empirically examined in previous studies (Compeau \& Higgins, 1995; Compeau, Higgins, \& Huff, 1999). This study posits a positive influence of computer selfefficacy on perceived ease of use of e-learning and also on perceived usefulness of e-learning. When a person belief in his/her capability to use computer as an enabler in information technology usage, he/she will use a computer in daily activities including learning. Accordingly, when a person belief in his/her capability to work with computer, then he/she will be closer to technology usage. Drawing from this mechanism and forgoing discussion, it can therefore be hypothesised that:

H1a: Computer self-efficacy positively influences perceived ease of use of e-learning.

H2a: Computer self-efficacy positively influences perceived usefulness of e-learning.

\section{Prior Experience and Acceptance Factors}

Numerous previous studies have demonstrated that prior computer experience has been founded to influence intention to use a variety of technology applications including microcomputers and internet banking services as well as e-learning (Igbaria, Guimaraes, \& Davis, 1995; Kerka, 1999; Sun \& Zhang, 2006; Tan \& Teo, 2000). Specifically, Lee et al. (2010) has found that individual experience 
with computer significantly affect perceived ease of use. Furthermore, according to McFarland and Hamilton (2006), an individual's emotional reaction to work with computers affects their perceived ease of use, perceived usefulness, and system usage.

This study predicts positive influences between prior experiences and perceived ease of use as well as between prior experiences and usefulness of e-learning. When a learner has previous experiences in using technology applied in various devices of life easily, he/she tends to perceive effortless to adopt e-learning. Moreover, the experienced learner tends to enjoy benefits provided by e-learning that gradually increase perceived usefulness of e-learning in working life. The relationship mechanism underlines a thought to propose that:

H1b: Prior experience positively influences perceived ease of use of e-learning.

$\mathrm{H} 2 \mathrm{~b}$ : Prior experience positively influences perceived usefulness of e-learning.

\section{Computer Anxiety and Acceptance Factors}

Howard and Smith (1986) defined computer anxiety as the tendency of a person to experience a level of uneasiness over his/her impending use of a computer. The definition of computer anxiety in this study is the level of learners' anxiety when they apply computers in e-learning (Sun, Tsai, Finger, Chen, \& Yeh, 2008). Computer anxiety has been related to negative perceptions about computers, problems in playing with them, and avoidance of the technology (Igbaria \& Iivari, 1995). Specifically, past research shows that computer anxiety influences how users perceived ease of use and perceived usefulness of an information system (Hackbarth, Grover, \& Yi, 2003; Saade \& Kira, 2009; Igbaria \& Iivari, 1995; Venkatesh \& Davis, 2000).

In the current study, negative relationships are proposed in the relations of computer anxiety and technology acceptance factors. The anxiety drives negative reactions to keep in distance with e-learning thus hindering the learner from e-learning occupation in working life. The proposed mechanism leads to these following hypotheses:

H1c: Computer anxiety negatively influences perceived ease of use of e-learning.

H2c: Computer anxiety negatively influences perceived usefulness of e-learning. 


\section{Internet Self-Efficacy and Acceptance Factors}

The current research confirmed that internet self-efficacy refers to an individual's ability to self-evaluate their internet usage and independently accomplish internet tasks (Torkzadeh \& Van Dyke, 2002; Tsai \& Lin, 2004; Tsai \& Tsai, 2003). Some researchers (Eastin \& LaRose, 2000; Hsu \& Chiu, 2003; Joo, Bong, \& Choi, 2000) confirmed that internet self-efficacy is one predictor of behaviour towards the intention to directly or indirectly use the internet. Specifically, Roca, Chiu, and Martinez (2006) and Lee et al. (2014) supported that internet self-efficacy was a significant predictor of perceived ease of use.

This study predicts positive influence of internet self-efficacy on e-learning acceptance factors. The belief of internet usage ability increases learner's openmindedness with various technology-based methods of learning since he/she perceives easiness of using e-learning. The internet self-efficacy also contributes to perceive usefulness of e-learning since a learner feels confidence to be interactive with e-learning and assumes its benefits based on his/her previous advantages received in various technology-based activities. In accordance with that psychological mechanism, this study therefore proposes that:

H1d: Internet self-efficacy positively influences perceived ease of use of e-learning.

$\mathrm{H} 2 \mathrm{~d}$ : Internet self-efficacy positively influences perceived usefulness of e-learning.

\section{Management Support and Acceptance Factors}

Perceived support is the employees' belief that the web-based training will be supported by management (Ali \& Magalhaes, 2008). Management refers to top level management in a company including leaders and direct supervisors. The term "management" may also refer to those people who manage an organisation (Stoner, 1995). Igbaria et al. (1995) emphasised that management support is required to obtain the top management encouragement, allocation of resources, and instructional development assistance. This management support is reported to be related to their perceptions of the ease of use, importance, and effectiveness of web-enhanced instruction (Walker, 2004). Leaders and supervisors need to play their roles in not only encouraging their employees to embrace self-directed learning via the internet, but also in improving employees' perception of web-based training (Hashim, 2008). Oentoro, Popaitoon, and Kongchan (2016) strengthened that there are a number of ways in which supervisors could support their employees such as providing key resources or providing emotional support 
in the form of sympathy, caring, comfort, and encouragement that strengthen employees' attachment to organisations. These supportive practices are expected to influence strong and positive feelings of employees' well-being as well as their working attitudes (Ng \& Sorensen, 2008). Ndubisi and Jantan (2003) found that perceived support was a significant predictor of technology acceptance including perceived usefulness and perceived ease of use. Venkatesh (1999) had also previously found that during the early stages of learning and using a system, perceived ease of use is significantly affected by management support. The current study from Walker (2004) and Purnomo and Lee (2012) demonstrated significant relationship between management supports and perceived ease of use and perceived usefulness of web-enhanced instruction.

The management support is assumed as assurance of e-learning's advantages thus strengthens a learner's perception of e-learning easiness and usefulness. This mechanism therefore leads to the following hypotheses:

H3: Management support positively influences perceived ease of use of e-learning.

H4: Management support positively influences perceived usefulness of e-learning.

\section{Moderating Effect of Management Support}

Many technology acceptance studies seem to neglect the moderating role of management support on the main proposed relationships in the current study (individual characteristics and e-learning acceptance factors relationships), although some do admit that the absence of such characteristics is one of their work's limitations (e.g., Davis, Bagozzi, \& Warshaw, 1989). Moderating factors are essential to explain contradictory findings in various studies (Davis et al., 1989; Sun \& Zhang, 2006). Sun and Zhang (2006) empirically examined the moderating factors of organisational, technological, and individual in individual characteristics with technology acceptance factors. However, the current study focuses on examining the management support's contribution as a moderating variable in the main relationship of individual characteristics and e-learning acceptance in individual level.

The role of management support is critical because the implementation of information system innovations is resource intensive (Sharma \& Yetton, 2003). Leonard-Barton and Deschamps (1988) suggested that employees whose characteristics incline them to adopt an innovation will do so without management support or urging if it is simply made available. Conversely, employees who are 
low on these characteristics will tend to wait for a managerial directive before adopting. Recently, study from Pastor and Perez (2015) found management support as the moderating role in sustaining ambidextrous learning through highinvolvement HR systems. This study supported that high-involvement HR systems were positively related to ambidextrous learning and validated the moderating role of management support.

This study proposes that management support moderates positively the relation between individual characteristics factors and e-learning acceptance factors. In accordance to perceived ease of e-learning using, a learner can utilise management support to strengthen his/her computer self-efficacy, prior experiences, and computer anxiety and easiness perception of using e-learning. When a learner has confidence in his/her ability to deal with computer and internet, he/she perceives that e-learning - a computer and internet-based learning - is easy to use. This relationship gets stronger when the management provides support for e-learning application at the company. While a learner has positive past experiences of using technology-based devices, he/she will also perceive that e-learning is easy to handle based on his/her previous experiences with technological practices. It can be expected that magnitude in the proposed main relationships is higher when management supports e-learning usage in the company. As for the negative relationship between computer anxiety and perceived ease to use of e-learning, management support also positively moderates. When a learner is experiencing anxiety with computer, he/she will perceive that e-learning is not easy to use. If management support is regarded highly in this context, the relationship is likely to be stronger since a learner can be expected to even believe that management support is needed to force individuals who perceive e-learning to be complicated. Under these mechanisms, the moderating hypotheses are posited as follows:

H5a: Management support positively moderates the relation of computer self-efficacy and perceived ease of use of e-learning. In which, a higher degree of management support will strengthen the magnitude of relationship between computer self-efficacy and perceived ease of use of e-learning.

H5b: Management support positively moderates the relation of prior experience and perceived ease of use of e-learning. In which, a higher degree of management support will strengthen the magnitude of relationship between prior experience and perceived ease of use of e-learning. 
H5c: Management support positively moderates the relation of computer anxiety and perceived ease of use of e-learning. In which, a higher degree of management support will strengthen the magnitude of relationship between computer anxiety and perceived ease of use of e-learning.

H5d: Management support positively moderates the relation of internet selfefficacy and perceived ease of use of e-learning. In which, a higher degree of management support will strengthen the magnitude of relationship between internet self-efficacy and perceived ease of use of e-learning.

Management support is also predicted to positively moderate the direct relation of individual characteristics and perceived usefulness of e-learning. Self-efficacy towards computer and internet increases perceived usefulness of e-learning. The magnitude of relationship is predicted to be higher when management support is available. The management support is perceived as an external support strengthening individual efficacy to enjoy the advantages of e-learning on dealing with jobs. Besides, positive relationship between prior experience and perceived usefulness of e-learning is predicted to be tighter with the existence of management support. A learner who has satisfactory experiences on using technology-based devices at work will assess e-learning as a beneficial system of learning in the organisation. When management facilitates the e-learning at work, a learner will perceive this external support as strengthen his/her perception of e-learning usefulness. In the case of the negative relationship between computer anxiety and perceived usefulness, management support is also predicted to have a positive moderating influence. The management support is perceived as external support that strengthen the negative relation since a learner may feel more pressured by the existence of an external demand coming from the company. Based on the foregoing discussion, the following hypotheses are postulated:

H6a: Management support positively moderates the relationship between computer self-efficacy and perceived usefulness of e-learning. In which, a higher degree of management support will strengthen the magnitude of relationship between computer self-efficacy and perceived usefulness of e-learning.

H6b: Management support positively moderates the relationship between prior experience and perceived usefulness of e-learning. In which, a higher degree of management support will strengthen the magnitude of relationship between prior experience and perceived usefulness of e-learning. 
H6c: Management support positively moderates the relationship between computer anxiety and perceived usefulness of e-learning. In which, a higher degree of management support will strengthen the magnitude of relationship between computer anxiety and perceived usefulness of e-learning.

H6d: Management support positively moderates the relationship between internet self-efficacy and perceived usefulness of e-learning. In which, a higher degree of management support will strengthen the magnitude of relationship between internet self-efficacy and perceived usefulness of e-learning.

Figure 1 shows the research framework in detail. Hypotheses in this study are developed using direct as well as indirect relationships by using management support as a moderating variable.

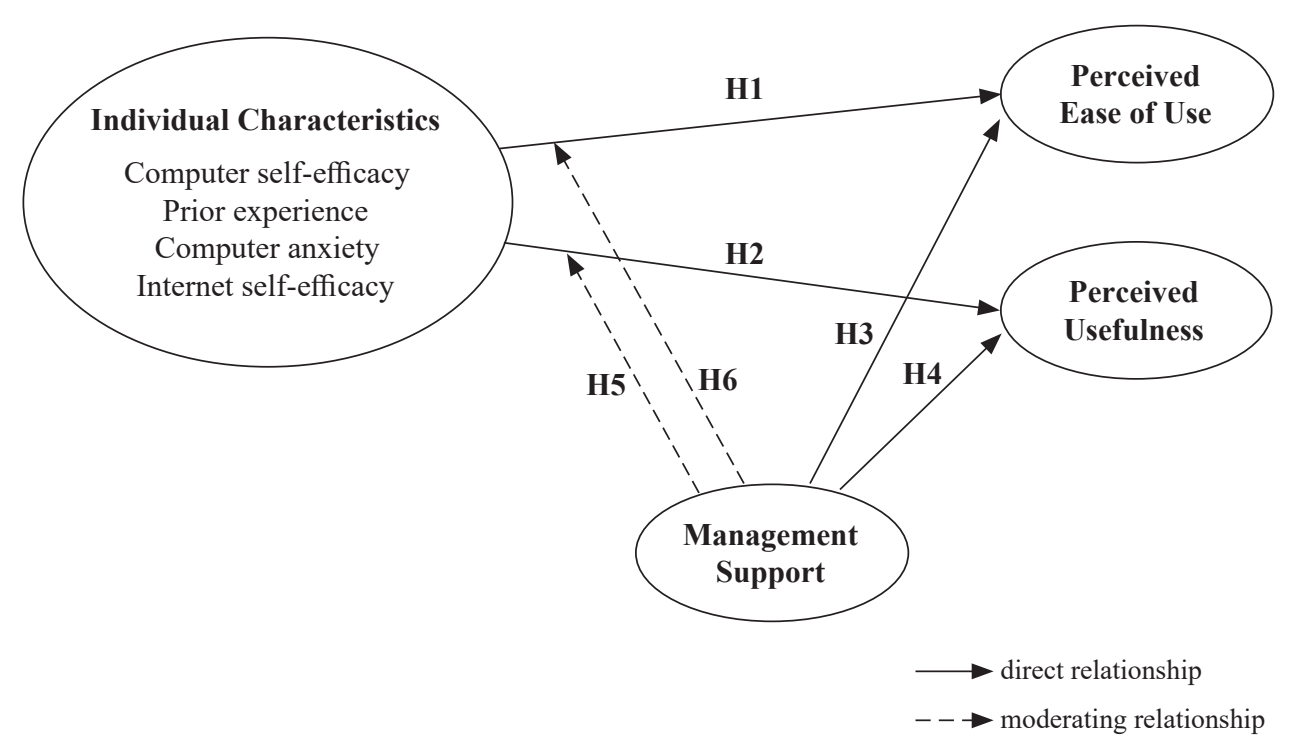

Figure 1. Research framework

\section{METHODS}

\section{Data Collection}

The link of online survey was sent by e-mail to a total of 500 individuals who had taken at least one e-learning course. We received a total of 343 responses. 
Since 37 questionnaires were incomplete, a total of 306 usable surveys were used, with a response rate of $61.20 \%$. A total of 306 employees in various departments from two companies participated as respondents in this study. Both companies were public banking companies in Indonesia banking industries with similarity in term of business nature. Thus, data collection within those two companies is controllable in term of minimising bias related to company dynamics. Gender distribution consisted of $60.52 \%$ male respondents. The age distribution shows that the highest number of respondents is in the range of 30-39 years old (44.41\%). In terms of job tenure, the majority of the respondents have tenure more than 10 years $(37.61 \%)$. The $33 \%$ of respondents were recorded as professional worker and most of them work in the marketing department (26.51\%). Additionally, most of them have experience in using computers for more than nine years $(64.72 \%)$.

\section{Measurement Development}

The completed instrument consists of two parts. Part I consisted of three subsections: (1) individual characteristic (computer self-efficacy, prior experience, computer anxiety, and internet self-efficacy); (2) management support; and (3) TAM construct (perceived ease of use and perceived usefulness). All items were measured using a 5-point Likert-type scale which anchors from "strongly disagree" to "strongly agree". Part II was designed to identify demographic attributes of the respondents. It contained demographic items on gender, age, educational background, and current working information such as work experience, job position, etc.

\section{Individual characteristics}

The measures of individual characteristics used in this study are taken from several previous studies: computer self-efficacy from Lee (2006), prior experience from Walker (2004), computer anxiety from Sun et al. (2008), and internet selfefficacy from Roca et al. (2006). Items for measuring the individual characteristics were selected for the purpose of this current study. There are four items in each construct of the individual characteristics including "computer self-efficacy" (e.g., I am confident that I can overcome any obstacles when using the computer for e-learning system), "prior experience" (e.g., I enjoy using computers), "computer anxiety" (e.g., working with a computer would make me very nervous), and "internet self-efficacy" (e.g., I feel confident in the e-learning system receiving and sending e-mail messages). The internal consistency reliability of the measurement instruments ranged from 0.80 to 0.92 . 


\section{Management support}

Items for management support were adapted from Ali (2005). Four items (e.g., I am always supported and encouraged by my boss to e-leaning system to perform my job) are included in the scale. The internal consistency reliability of the measure is 0.75 .

\section{Technology acceptance constructs}

Item developed by Venkatesh and Moris (2000) and then being adapted from Davis (1989) was used in this study. The two constructs of TAM were used, including perceived ease of use (e.g., I find the e-learning system to be easy to use) and perceived usefulness (e.g., Using the e-learning system enhances my effectiveness in my learning). The internal consistency reliability ranged from 0.79 to 0.85 .

\section{RESULTS}

\section{Measurement Validation}

To verify the validity and reliability of the measures, we observed the factor loadings from the confirmatory factor analysis (CFA) assessing the measurement model. Based on Fornell and Larcker (1981) recommendation, we used three criteria to assess convergent validity. The three criteria are: (1) all indicator factors loading should be exceeding $0.50 ;(2)$ composite reliabilities should be exceeding 0.70 ; and (3) average variance extracted (AVE) should be equal or exceed 0.50 . All measurement values in CFA of the measurement model were exceeding the threshold value. All factors loading exceeded 0.50; composite reliabilities of constructs ranged from 0.81 to 0.93 , and AVE ranged from 0.51 to 0.63 (see Table 1). Convergent validity was assessed based on the criteria that the indicator's estimated coefficient was significant on its posited underlying construct factor. Therefore, all three conditions for convergent validity were achieved. Table 1 also provides details of mean, standard deviation, and convergent validity analysis. The results of measurement model obtained a ratio of chi-square to the degree of freedom $(\mathrm{X} 2 / \mathrm{df})=1.68$, goodness of fit index $(\mathrm{GFI})=0.90$, adjusted goodness of fit index $(\mathrm{AGFI})=0.87$, comparative fit index $(\mathrm{CFI})=0.94$, and Root Mean Square Error of Approximation $($ RMSEA $)=0.05$. Generally, fit statistics greater than or equal to 0.9 for GFI, normed fit index (NFI), relative fit index (RFI), CFI, and 0.8 
for AGFI indicate a good model fit (Bagozzi, Yi, \& Phillips, 1991; Hair, Anderson, Tatham, \& Black, 1998). Furthermore, RMSEA values ranging from 0.05 to 0.08 are acceptable (Hair et al. 1998). Therefore, the RMSEA suggested that our model fit was acceptable.

Table 1

Mean, standard deviation, and convergent validity analysis $(n=306)$

\begin{tabular}{|c|c|c|c|c|c|c|}
\hline Constructs/Factor & Indicator & Mean & $\begin{array}{l}\text { Standard } \\
\text { deviation }\end{array}$ & $\begin{array}{l}\text { Standardised } \\
\text { loading }\end{array}$ & $\begin{array}{l}\text { Composite } \\
\text { reliability }\end{array}$ & AVE \\
\hline \multirow[t]{4}{*}{ Computer self-efficacy } & CSE1 & 4.16 & 0.67 & 0.79 & 0.85 & 0.60 \\
\hline & CSE2 & 4.12 & 0.69 & 0.85 & & \\
\hline & CSE3 & 4.16 & 0.73 & 0.79 & & \\
\hline & CSE4 & 4.03 & 0.65 & 0.65 & & \\
\hline \multirow[t]{4}{*}{ Prior experience } & PE1 & 3.55 & 0.86 & 0.75 & 0.83 & 0.55 \\
\hline & PE2 & 3.61 & 0.77 & 0.78 & & \\
\hline & PE3 & 3.59 & 0.80 & 0.79 & & \\
\hline & PE4 & 3.63 & 0.72 & 0.63 & & \\
\hline \multirow[t]{4}{*}{ Computer anxiety } & $\mathrm{AX} 1$ & 3.91 & 0.99 & 0.85 & 0.93 & 0.76 \\
\hline & AX2 & 3.97 & 1.02 & 0.89 & & \\
\hline & AX3 & 4.09 & 0.91 & 0.87 & & \\
\hline & $\mathrm{AX} 4$ & 3.92 & 0.97 & 0.88 & & \\
\hline \multirow[t]{4}{*}{ Internet self-efficacy } & ISE1 & 3.08 & 1.03 & 0.75 & 0.87 & 0.63 \\
\hline & ISE2 & 3.83 & 0.91 & 0.72 & & \\
\hline & ISE3 & 3.49 & 1.04 & 0.86 & & \\
\hline & ISE4 & 3.09 & 0.98 & 0.84 & & \\
\hline \multirow[t]{4}{*}{ Management support } & MS1 & 3.97 & 0.73 & 0.71 & 0.82 & 0.53 \\
\hline & MS2 & 3.72 & 0.82 & 0.79 & & \\
\hline & MS3 & 4.14 & 0.67 & 0.57 & & \\
\hline & MS4 & 3.72 & 0.79 & 0.82 & & \\
\hline \multirow[t]{4}{*}{ Perceived ease of use } & PEU1 & 3.44 & 0.80 & 0.78 & 0.86 & 0.61 \\
\hline & PEU2 & 3.65 & 0.72 & 0.79 & & \\
\hline & PEU3 & 3.55 & 0.76 & 0.81 & & \\
\hline & PEU4 & 3.63 & 0.73 & 0.73 & & \\
\hline \multirow[t]{4}{*}{ Perceived usefulness } & PU1 & 3.96 & 0.69 & 0.79 & 0.81 & 0.51 \\
\hline & PU2 & 4.00 & 0.70 & 0.77 & & \\
\hline & PU3 & 3.96 & 0.74 & 0.66 & & \\
\hline & PU4 & 4.01 & 0.65 & 0.61 & & \\
\hline
\end{tabular}


Discriminant validity assesses the extent to which a concept and its indicators differ from another concept and its indicators (Bagozzi et al., 1991). According to Fornell and Larcker (1981), the correlations between items in any two constructs should be lower than the square root of the average variance shared by items within a construct. As shown in Table 2, the square root of the variance shared between a construct and its items was greater than the correlations between the construct and any other construct in the model, hence, satisfying Fornell and Larckers' (1981) criteria for discriminant validity. All diagonal values exceeded the inter-construct correlations. The results, therefore, confirmed that our instruments had satisfactory construct validity.

Table 2

Mean, standard deviation, reliability, and correlation coefficient among variables

\begin{tabular}{lccccccccc}
\hline Variable & Mean & SD & 1 & 2 & 3 & 4 & 5 & 6 & 7 \\
\hline 1. Computer self-efficacy & 4.12 & 0.54 & $\mathbf{0 . 7 7}$ & & & & & & \\
2. Prior experience & 3.60 & 0.63 & 0.16 & $\mathbf{0 . 7 4}$ & & & & & \\
3. Computer anxiety & 3.97 & 0.87 & 0.36 & 0.12 & $\mathbf{0 . 8 7}$ & & & & \\
4. Internet self-efficacy & 3.37 & 0.79 & 0.08 & 0.04 & 0.20 & $\mathbf{0 . 7 9}$ & & & \\
5. Management support & 3.89 & 0.57 & 0.15 & 0.23 & 0.06 & 0.08 & $\mathbf{0 . 7 3}$ & & \\
6. Perceived ease of use & 3.57 & 0.63 & 0.21 & 0.58 & 0.13 & 0.14 & 0.27 & $\mathbf{0 . 7 8}$ & \\
7. Perceived usefulness & 3.98 & 0.54 & 0.23 & 0.43 & 0.21 & 0.11 & 0.44 & 0.46 & $\mathbf{0 . 7 1}$ \\
\hline
\end{tabular}

Note: Diagonals represent the square roots of AVE and the other matrix entries are the factor correlations

\section{Descriptive Statistic and Correlation among Construct}

Table 2 presents the means, standard deviations, reliabilities, and bivariate correlations among the study variables. For the constructs of individual characteristic, they significantly correlated with perceived ease of use and perceived usefulness. The correlation coefficients ranged from 0.04 to 0.58 $(p<0.01)$. Management support is significantly correlated with perceived ease of use $(r=0.27 ; p<0.01)$ and perceived usefulness $(r=0.44 ; p<0.01)$. Meanwhile, among individual characteristics, internet self-efficacy only significantly correlated with computer anxiety $(r=0.20 ; p<0.01)$.

\section{Hypothesis Testing}

Table 3 summarises the results of hierarchical regression analyses of research hypotheses. Moderator testing with hierarchical regression analysis based on Baron and Kenny (1986) procedures was applied in the hypothesis testing. The independent variables along with the product term were centered on the mean in 
order to process the testing for moderation effects. The independent variables were individual characteristic, and dependent variables were perceived ease of use and perceived usefulness. In addition, the hierarchical regression analysis was used for testing the moderation effects of management support to the aforementioned relationship.

In the hierarchical regression analysis, independent variables were entered in several steps (Baron \& Kenny, 1986). In the first step, we entered individual characteristics. Results revealed that each of prior experience $(\beta=0.58 ; p<0.01)$ and computer anxiety $(\beta=-0.12 ; p<0.01)$ has significant influence towards perceived ease of use. In the second step, management support was added as a predictor of perceived ease of use. A significant beta coefficient was reported $(\beta=0.14 ; p<0.01)$. For testing the moderating effects of management support on the relationship between individual characteristic and technology acceptance constructs, we then entered interaction in step 3. As shown in Table 3, only interaction between prior experience and management support significantly predicted towards perceived ease of use $(\beta=0.59 ; p<0.05)$. Overall, test of the moderation effect in step 3 have no significant $F$-changes on the relationship between the dependent and independent variables.

Table 3

Hierarchical regression analysis results for perceived ease of use

\begin{tabular}{|c|c|c|c|c|c|c|}
\hline \multirow{3}{*}{ Independent variables } & \multicolumn{6}{|c|}{ Perceived ease of use } \\
\hline & \multicolumn{2}{|c|}{ Step 1} & \multicolumn{2}{|c|}{ Step 2} & \multicolumn{2}{|c|}{ Step 3} \\
\hline & $\beta$ & $T$ & $\beta$ & $t$ & $\beta$ & $t$ \\
\hline 1. CSE & 0.06 & $1.14^{\mathrm{ns}}$ & 0.04 & $0.83^{\mathrm{ns}}$ & 0.17 & $0.56^{\mathrm{ns}}$ \\
\hline 2. $\mathrm{PE}$ & 0.58 & $12.37^{* *}$ & 0.55 & $11.61^{* *}$ & 0.59 & $1.90^{*}$ \\
\hline 3. $\mathrm{AX}$ & -0.12 & $-2.39^{* *}$ & -0.12 & $-2.38^{* *}$ & -0.46 & $-1.22^{\mathrm{ns}}$ \\
\hline 4. ISE & 0.03 & $0.70^{\mathrm{ns}}$ & 0.02 & $0.49^{\mathrm{ns}}$ & 0.34 & $0.97^{\mathrm{ns}}$ \\
\hline 5. MS & & & 0.14 & $3.01^{* *}$ & 0.10 & $-0.22^{\mathrm{ns}}$ \\
\hline 6. $\mathrm{CSE} \times \mathrm{MS}$ & & & & & 0.35 & $0.69^{\text {ns }}$ \\
\hline 7. $\mathrm{PE} \times \mathrm{MS}$ & & & & & -0.05 & $0.11^{\mathrm{ns}}$ \\
\hline 8. $\mathrm{AX} \times \mathrm{MS}$ & & & & & 0.42 & $0.90^{\text {ns }}$ \\
\hline 9. ISE $\times$ MS & & & & & 0.39 & $0.91^{\mathrm{ns}}$ \\
\hline $\mathrm{R}^{2}$ & \multicolumn{2}{|c|}{0.35} & \multicolumn{2}{|c|}{0.37} & \multicolumn{2}{|c|}{0.37} \\
\hline$\Delta \mathrm{R}^{2}$ & \multicolumn{2}{|c|}{0.35} & \multicolumn{2}{|c|}{0.02} & \multicolumn{2}{|c|}{0.00} \\
\hline$F$-change & \multicolumn{2}{|c|}{40.33} & \multicolumn{2}{|c|}{9.05} & \multicolumn{2}{|c|}{0.69} \\
\hline Sig $F$-change & \multicolumn{2}{|c|}{0.00} & \multicolumn{2}{|c|}{0.00} & \multicolumn{2}{|c|}{0.60} \\
\hline
\end{tabular}

Note: ${ }^{* *} p<0.01 ;{ }^{*} p<0.05 ; \mathrm{ns}=$ not significant; CSE = computer self-efficacy; $\mathrm{PE}=$ past experience; $\mathrm{AX}=$ computer anxiety; ISE = internet self-efficacy; MS = management support 
The results for predictions regarding the second dependent variable, perceived usefulness, are shown in Table 4 . The results of step 1 showed that three individual characteristics were found to significantly predict perceived usefulness. They are computer self-efficacy $(\beta=0.12 ; p<0.05)$, prior experience $(\beta=0.40 ; p<0.01)$, and computer anxiety $(\beta=0.11 ; p<0.05)$. In step 2 of hierarchical regression analysis, we focused on management support. The result revealed management support $(\beta=0.34, p<0.01)$ significantly predicted perceived usefulness. While, in step 3 , the result revealed that interaction between prior experience and management support $(\beta=0.99 ; p<0.05)$ and internet self-efficacy and management support $(\beta=0.90 ; p<0.05)$ significantly predicted to perceived usefulness. That findings indicate that there is a positive moderating effect $(F$-change $=0.03$; $p<0.05$ ) of management support to the aforementioned relationship.

Table 4

Hierarchical regression analysis results for perceived usefulness

\begin{tabular}{|c|c|c|c|c|c|c|}
\hline \multirow{3}{*}{ Independent variables } & \multicolumn{6}{|c|}{ Perceived usefulness } \\
\hline & \multicolumn{2}{|c|}{ Step 1} & \multicolumn{2}{|c|}{ Step 2} & \multicolumn{2}{|c|}{ Step 3} \\
\hline & $\beta$ & $t$ & $\beta$ & $t$ & $\beta$ & $t$ \\
\hline 1. CSE & 0.12 & $2.14^{*}$ & 0.08 & $1.54^{\mathrm{ns}}$ & 0.36 & $1.18^{\text {ns }}$ \\
\hline 2. $\mathrm{PE}$ & 0.40 & $7.78^{* *}$ & 0.33 & $6.73^{* *}$ & 1.01 & $3.23^{* *}$ \\
\hline 3. $\mathrm{AX}$ & 0.11 & $2.03^{*}$ & 0.12 & $2.28^{* *}$ & 0.48 & $1.27^{\mathrm{ns}}$ \\
\hline 4. ISE & 0.07 & $1.29^{\mathrm{ns}}$ & 0.04 & $0.89^{\mathrm{ns}}$ & 0.78 & $2.21^{*}$ \\
\hline 5. MS & & & 0.34 & $6.99^{* *}$ & 1.11 & $2.53^{*}$ \\
\hline 6. $\mathrm{CSE} \times \mathrm{MS}$ & & & & & 0.75 & $1.48^{\mathrm{ns}}$ \\
\hline 7. $\mathrm{PE} \times \mathrm{MS}$ & & & & & 0.99 & $2.20^{*}$ \\
\hline 8. $\mathrm{AX} \times \mathrm{MS}$ & & & & & 0.47 & $0.98^{\text {ns }}$ \\
\hline 9. ISE $\times$ MS & & & & & 0.91 & $2.08^{*}$ \\
\hline $\mathrm{R}^{2}$ & \multicolumn{2}{|c|}{0.23} & \multicolumn{2}{|c|}{0.34} & \multicolumn{2}{|c|}{0.36} \\
\hline$\Delta \mathrm{R}^{2}$ & \multicolumn{2}{|c|}{0.23} & \multicolumn{2}{|c|}{0.11} & \multicolumn{2}{|c|}{0.02} \\
\hline$F$-change & \multicolumn{2}{|c|}{22.67} & \multicolumn{2}{|c|}{48.85} & \multicolumn{2}{|c|}{2.80} \\
\hline Sign $F$-change & \multicolumn{2}{|c|}{0.00} & \multicolumn{2}{|c|}{0.00} & \multicolumn{2}{|c|}{$0.03^{*}$} \\
\hline
\end{tabular}

Note: ${ }^{* *} p<0.01 ;{ }^{*} p<0.05$

Hypothesis 1 states that individual characteristic will be positively related to perceived ease of use. The findings showed that of the four-characteristics only two characteristics were positively related to perceived ease of use. These were prior experience and computer anxiety. Hence, H1b and H1c were supported. Hypothesis 2 stated that individual characteristics will be positively related to perceived usefulness. The results showed that computer self-efficacy and prior 
experience positively influenced perceived usefulness, while computer anxiety negatively predicted to perceived usefulness. Therefore, $\mathrm{H} 2 \mathrm{a}, \mathrm{H} 2 \mathrm{~b}$, and $\mathrm{H} 2 \mathrm{c}$ were supported.

$\mathrm{H} 3$ and $\mathrm{H} 4$ stated that management support will be positively related to perceive ease of use and perceived usefulness. The result revealed that management support positively predicts both dependent variables, hence $\mathrm{H} 3$ and $\mathrm{H} 4$ were supported.

Finally, hypotheses 5 and 6 examine the moderation effect of management support. Hypotheses 5 posited that management support positively moderates the relation between individual characteristics and perceived ease of use of e-learning, in which, a higher degree of management support will strengthen the magnitude of relationship between individual characteristic and perceived ease of use of e-learning. Moreover, hypotheses 6 stated that management support positively moderates the relationship between individual characteristics and perceived usefulness of e-learning, in which, a higher degree of management support will strengthen the magnitude of relationship between individual characteristic and perceived usefulness of e-learning. The findings showed no supports for any of hypotheses 5. Furthermore, results of hypotheses 6 showed that management support moderates the relationship between prior experience and perceived usefulness of e-learning. Accordingly, H6b was supported and no supports for H6a, H6c, and H6d were found. Table 5 provides a summary of the hypotheses tested. Lee et al. (2010) found that the role of management was perceived by the employees as that of facilitators and supporters of the use of e-learning systems. $\mathrm{H} 3$ and $\mathrm{H} 4$ found that employees tended to perceive the e-learning system as easy to use. Based on TAM theories (Davis, 1989), if users feel the system is easy to use, they will feel that e-learning is useful and they will be prepared to use the technology. On the other hand, this study revealed that only prior experience moderates by management support in relationship with perceived usefulness of e-learning. One possible explanation is that the respondents were highly computer literate. This makes an individual feel at ease in using computers and may thus decrease the importance of management support. 
Table 5

Summary: Results of hypotheses testing

\begin{tabular}{lccl}
\hline Hypotheses & Independent variables & Dependent variables & \multicolumn{1}{c}{ Results } \\
\hline H1a & CSE & PEU & Not supported \\
H1b & PE & & Supported $(p<0.01)$ \\
H1c & AX & Supported $(p<0.01)$ \\
H1d & ISE & & Not supported \\
H2a & CSE & PU & Supported $(p<0.05)$ \\
H2b & PE & & Supported $(p<0.01)$ \\
H2c & AX & Supported $(p<0.05)$ \\
H2d & ISE & Not supported \\
H3 & MS & & Supported $(p<0.01)$ \\
H4 & MS & PEU & Supported $(p<0.01)$ \\
H5a & PU $\times$ MS & Not supported \\
H5b & PE $\times$ MS & PEU & Supported $(p<0.05)$ \\
H5c & AX $\times$ MS & & Not supported \\
H5d & ISE $\times$ MS & Not supported \\
H5e & Ind Char $\times$ MS & & Not supported \\
H6a & CSE $\times$ MS & & Not supported \\
H6b & PE $\times$ MS & Supported $(p<0.05)$ \\
H6c & AX $\times$ MS & & Not supported \\
H6d & ISE $\times$ MS & Supported $(p<0.05)$ \\
H6e & Ind Char $\times$ MS & PU & \\
\hline & & & Supported $(p<0.05)$ \\
\hline
\end{tabular}

\section{DISCUSSION}

This study demonstrated that some individual characteristics were positively affected to perceived ease of use. Of the four individual characteristics, only prior experience and computer anxiety showed significant impact on perceived ease of use. On the other hand, computer and internet self-efficacy had no significant impact on perceived ease of use.

It was shown by the results of this study that prior experience significantly affects perceived ease of use. This result confirms the past research that prior experience influences users' intention to use various technology applications (e.g., e-learning) (McFarland \& Hamilton, 2006; Tan \& Teo, 2000). Besides, this result also proves study from Taylor and Todd (1995) that there are some significant differences in 
the relative influence of the determinants of IT usage depending on experience. This conclusion is reasonable given to the definition of perceived ease of use taken from Davis (1989) that a person who has prior experience would believe in free physical or mental effort to use computer and or internet.

Computer anxiety has a negative effect on perceived ease of use which implies that the greater the anxiety, the lower of perceived ease of e-learning usage. Heinssen, Glass, and Knight (1987) noted that computer anxiety is a kind of state anxiety which represents beliefs and feelings towards computers. Furthermore, their study found that a higher level of computer anxiety causes a lower level of learning satisfaction. That finding confirms that level of anxiety influences the feeling of satisfaction and easiness of employees towards e-learning system.

The result obtained from the analysis of computer self-efficacy and internet self-efficacy relationship in previous studies was found to be inconsistent with the current study finding. Whereas numerous prior studies (e.g., Agarwal, Sambamurthy, \& Stair, 2000; Chau, 2001; Davis, 1989; Hong, Thong, Wong, \& Tam, 2001; Lee, 2006) supported that this factor has a significant influence on e-learning adoption; the current study on the contrary, revealed that computer selfefficacy and internet self-efficacy were not affecting perceived ease of use. One possible explanation that may account for this finding relates to how learners may define ease of use concept. Davis (1989) defined ease of use as free from effort in using e-learning system. In becoming a free from effort user, a person needs to have all the competencies needed by an e-learning user, not only basic competencies such as computer and internet, but also the advanced ones, such as networking and knowledge management. Thus, self-efficacy through computer and internet may only contribute less towards perceived ease of use in e-learning as the construct provides only the basic competencies of using e-learning. The finding notes the importance of various training, not only computer and internet, but that employees should be urged to occupy e-learning in their working activities.

Overall, individual characteristics have significant impact on perceived usefulness. Of the four individual characteristics, three characteristics demonstrated strong relationship, but internet self-efficacy has no significant impact on perceived usefulness. The supported findings are aligned with previous studies on the contribution of computer self-efficacy (e.g., Hayashi et al., 2004; Venkatesh \& Davis, 1996), prior experience (e.g., McFarland \& Hamilton, 2006; Tan \& Teo, 2000), and computer anxiety (e.g., Hackbarth et al., 2003; Igbaria \& Iivari, 1995; Saade \& Kira, 2009; Venkatesh \& Davis, 2000) on perceived usefulness of using e-learning. An individual's self-efficacy towards computers increases his/her 
interactions with e-learning as a technology-based learning system. The intensive interaction thus contributes to his/her perceived usefulness of e-learning at work. Moreover, the experienced learner enjoys benefits provided by technology-based devices that gradually increase perceived usefulness of e-learning in working life. Oppositely, those who have an uneasiness feeling of using computer will keep in distance with technology-based devices thus hindering the learner from opportunity to enjoy e-learning's benefit.

The finding shows no significant contribution of internet self-efficacy to perceived usefulness of e-learning. Internet self-efficacy is distinguished from computer selfefficacy as the belief that one can successfully perform a distinct set of behaviours required to establish, maintain, and utilise effectively the internet over and above basic personal computer skills (Eastin \& LaRose, 2000). Those with internet self-efficacy may have wider knowledge of utilising technology-based device in return to enjoying its usefulness. However, they may understand how complicated e-learning access is since various competencies and skills are needed to be an e-learning user, not only computer, but also internet, networking, and knowledge management. Thus, internet self-efficacy is only a partially needed competency that may not be enough to support individual perceived usefulness of accessing e-learning benefits in work-related activities. This argument may be posited to explain the unsupported finding of internet self-efficacy effect through perceived usefulness of e-learning.

Consistent with the hypothesis, management support was positively related to both perceived ease of use and perceived usefulness. Therefore, management support has an important influence on acceptance factors that improve e-learning adoption. Baldwin and Ford (1988) stated that senior management support and organisation atmosphere have a direct impact on training effectiveness and application rate. The more support trainees receive from their seniors, the better learning performance will be achieved (Lim, 2001; Oentoro et al., 2016). A learner assumes that management support is an assurance of e-learning's advantages at work place, thus strengthen perceived ease and usefulness of e-learning.

While management support directly contributes to perceived e-learning acceptance factors, the findings do not show much of its contribution as a moderating variable in the relationship between individual characteristics and e-learning acceptance constructs. Support is not found in all moderating hypotheses of management support in the relationship between individual characteristics and perceived ease of use. While positive relationships found in direct relationship between prior experiences, computer anxiety and perceived ease of use, the management support 
does not moderate these relationships. The findings show that high magnitude of personal things (e.g., anxiety) in the past experienced by the individuals that is not interrupted by recent management action can potentially influence a learner's perception of e-learning ease of use.

Of all the moderating effects of management support in the individual characteristics and perceived usefulness relationships, a significant support of management support as a moderator with a positive effect is only provided in the relationship between prior experiences and perceived usefulness of e-learning. The finding shows that the existence of management support in terms of policies and facilities will strengthen the positive relationship between tangible prior activities experienced by a learner and his/her perceived usefulness of e-learning. However, the moderating effect of management support does not significantly contribute to the relationship between psychological factors (e.g., computer self-efficacy, computer anxiety, internet self-efficacy) of an individual on e-learning acceptance constructs. The findings may shed light for future studies on the importance of management support in elucidating the relationship between tangible individual characteristics (e.g., prior experiences) and e-learning acceptance.

The current research findings urge future studies to consider develop a higher consideration on the effect of individual characteristics and management support in e-learning application within a company. In general, managers should consider employee computer self-efficacy, prior experiences, computer anxiety, and internet self-efficacy as essential factors on the effectiveness of e-learning acceptance in their companies. Moreover, consideration on other personal competencies such as knowledge management and networking may also be beneficial to increase e-learning acceptance. Management support, in terms of consideration, policy, and facilities, is also valuable in developing an appropriate acceptance of e-learning application in a company. The management support shows the managers' commitment and assurance of e-learning benefits thus strengthening employees' willingness to use e-learning, especially for those who previously experienced in using technology-based devices.

\section{CONCLUSION}

In general, this study contributes to the empirical examination of the relationship between individual characteristics and management support to e-learning acceptance factors which are represented by perceived ease of use and perceived usefulness. Management support has showed its importance in elucidating the 
relationship between prior experiences and e-learning acceptance. It is hoped that this study will act as a springboard to stimulate more research to investigate the impact of management support and other related constructs in the main relationship between individual characteristics and e-learning acceptance factors.

\section{Limitations and Further Research}

Like any study, this study is subject to its limitations. First, this study adopts a cross-section research design. Future studies may consider conducting a similar study using a longitudinal study because longitudinal studies can potentially add more insights that can hardly be captured in a cross-sectional survey utilised in the current study. Second, the problem of common method variance might occur due to the fact that data were collected from self-report questionnaire. In this study, steps were taken to prevent the potential bias derived from this method. Anonymity was thus guaranteed. Further studies might consider collecting data from different sources to increase the level of research generalisability.

\section{ACKNOWLEDGEMENTS}

This work was supported by PNBP Universitas Sebelas Maret research grant "Peningkatan Kapasitas Grup Riset" with grant number 76/UN27.21/PP/2017.

\section{REFERENCES}

Agarwal, R., Sambamurthy, V., \& Stair, R.M. (2000). Research report: The evolving relationship between general and specific computer self-efficacy - An empirical assessment. Information Systems Research, 11(4), 418-430. https://doi. org/10.1287/isre.11.4.418.11876

Ali, A.S.B. (2005). An assessment of the impact of the fit among computer self-efficacy, task characteristic, and system characteristic on performance and information system utilization. $\mathrm{PhD}$ dissertation, The George Washington University, USA.

Ali, G.E., \& Magalhaes, R. (2008). Barriers to implementing e-learning: A Kuwaiti case study. International Journal of Training and Development, 12(1), 36-53. https://doi.org/10.1111/j.1468-2419.2007.00294.x

Bagozzi, R.P., Yi, Y., \& Phillips, L.W. (1991). Assessing construct validity in organizational research. Admin Science Quarts, 36(3), 421-430. https://doi.org/10.2307/2393203

Baldwin, T.T., \& Ford, J.K. (1988). Transfer of training: A review and directions for future research. Personnel Psychology, 41(1), 63-105. https://doi. org/10.1111/j.1744-6570.1988.tb00632.x 
Baron, R.M., \& Kenny, D.A. (1986). The moderator-mediator variable distinction in social psychological research: Conceptual, strategic, and statistical considerations. Journal of Personality and Social Psychology, 51(6), 1173-1182. https://doi. org/10.1037//0022-3514.51.6.1173

Chau, P.Y.K. (2001). Influence of computer attitude and self-efficacy on IT usage behavior. Journal of End User Computing, 13(1), 26-33. https://doi.org/10.4018/ joeuc. 2001010103

Compeau, D.R., \& Higgins, C.A. (1995). Computer self-efficacy: Development of a measure and initial test. MIS Quarterly, 19(2), 189-211. https://doi.org/10.2307/249688

Compeau, D.R., Higgins, C.A., \& Huff, S. (1999). Social cognitive theory and individual reactions to computing technology: A longitudinal study. MIS Quarterly, 23(2), 145-158. https://doi.org/10.2307/249749

Davis, F.D. (1989). Perceived usefulness, perceived ease of use, and user adoption of IT. MIS Quarterly, 13(3), 319-340. https://doi.org/10.2307/249008

Davis, F.D., Bagozzi, R.P., \& Warshaw, P.R. (1989). User acceptance of computer technology: A comparison of two theoretical models. Management Science, 35(8), 982-1003. https://doi.org/10.1287/mnsc.35.8.982

de Alva, J.K. (2000). Remaking the academy. Educause, (March/April), 32-40.

Dong, F., Neufeld, D., \& Higgins, C. (2009). Top management support of enterprise systems implementations. Journal of Information Technology, 24(1), 555-580.

Eastin, M.S., \& LaRose, R. (2000). Internet self-efficacy and the psychology of the digital divide. Journal of Computer-Mediated Communication, 6(1), JCMC611. https://doi.org/10.1111/j.1083-6101.2000.tb00110.x

Fornell, C., \& Larcker, D.F. (1981). Evaluating structural equation models with unobservable variables and measurement error. Journal of Marketing Research, 18(1), 39-50. https://doi.org/10.1177/002224378101800104

Grandon, E.E., Alshare, K., \& Kwun, O. (2005). Factors influencing student intention to adopt online classes: A cross-cultural study. Journal of Computing Science in College, 20(4), 46-56.

Hackbarth, G., Grover, V., \& Yi, M.Y. (2003). Computer playfulness and anxiety: Positive and negative mediators of the system experience effect on perceived ease of use. Information \& Management, 40(3), 221-232. https://doi.org/10.1016/s03787206(02)00006-X

Hair, J.F. Jr., Anderson, R.E., Tatham, R.L., \& Black, W.C. (1998). Multivariate data analysis (5th ed.). New Jersey: Prentice-Hall.

Hairston, N.R. (2007). Employees' attitude toward e-learning: Implications for policy in industry environments. PhD dissertation, University of Arkansas, Ann Arbor, USA.

Hashim, J. (2008). Factors influencing the acceptance of web-based training in Malaysia: Applying the technology acceptance model. International Journal of Training and Development, 12(4), 253-264. https://doi.org/10.1111/j.1468-2419.2008.00307.x

Hayashi, A., Chen, C., Ryan, T., \& Wu, J. (2004). The role of social presence and moderating role of computer self-efficacy in predicting the continuance usage of e-learning systems. Journal of Information Systems Education, 15(2), 139-154. 
Heinssen, R.K., Glass, C.R., \& Knight, L.A. (1987). Assessing computer anxiety: Development and validation of the computer anxiety rating scale. Computers in Human Behavior, 3(1), 49-59. https://doi.org/10.1016/0747-5632(87)90010-0

Hong, W., Thong, J.Y.L., Wong, W.M., \& Tam, K.Y. (2001). Determinant of user acceptance of digital libraries: An empirical examination individual differences and system characteristics. Journal of Management Information Systems, 18(3), 97-124. https://doi.org/10.1080/07421222.2002.11045692

Howard, S.G., \& Smith, D.R. (1986). Computer anxiety in management: Myth or reality? Communications of the ACM, 29(7), 611-615. https://doi.org/10.1145/6138.6143

Hsu, M.H., \& Chiu, C.M. (2003). Internet self-efficacy and electronic service acceptance. Decision Support Systems, 38(3), 381-369. https://doi.org/10.1016/j. dss.2003.08.001

Hussein, R., Aditiawarman, U., \& Mohamed, N. (2007). E-learning acceptance in a developing country: A case of the Indonesian Open University. Paper presented at German e-Science Conference, Baden-Baden, Germany.

Igbaria, M., Guimaraes, T., \& Davis, G.B. (1995). Testing the determinants of microcomputer usage via a structural equation model. Journal of Management Information Systems, 11(4), 87-114.

Igbaria, M., \& Iivari, J. (1995). The effects of self-efficacy on computer usage. Omega, 23(6), 587-605. https://doi.org/10.1080/07421222.1995.11518061

Jirachiefpattana, W. (2015). Using individual values of information technology to improve software development management practices in Thailand. Asian Academy of Management Journal, 20(1), 49-69.

Joo, Y., Bong, M., \& Choi, H.J. (2000). Self-efficacy for self-regulated learning, academic self-efficacy, and internet self-efficacy in web-based instruction. Educational Technology Research and Development, 48(2), 5-17. https://doi.org/10.1007/ bf02313398

Kerka, S. (1999). Distance learning, the internet, and the World Wide Web. ERIC Digest (ERIC Document Reproduction Service No. ED 395214). http://www.ericdigests. org/1997-1/distance.html

Lee, Y.C. (2006). An empirical investigation into factors influencing the adoption of an e-learning system. Online Information Review, 30(5), 517-541. https://doi. org/10.1108/14684520610706406

Lee, Y.H., Hsiao, C., \& Purnomo, S.H. (2014). An empirical examination of individual and system characteristics on enhancing e-learning acceptance. Australian Journal of Educational Technology, 30(5), 562-579. https://doi.org/10.14742/ajet.381

Lee, Y.H., Hsieh, Y.C., \& Ma, C.Y. (2010). A model of organizational employees' e-learning systems acceptance. Knowledge-Based Systems, 24(3), 355-366. https://doi.org/10.1016/j.knosys.2010.09.005

Leonard-Barton, D., \& Deschamps, I. (1988). Managerial influence in the implementation of new technology. Management Science, 34(10), 1252-1266. https://doi. org/10.1287/mnsc.34.10.1252

Lim, C.K. (2001). Computer self-efficacy, academic self-concept, and other predictors of satisfaction and future participation of adult distance learners. American Journal of Distance Education, 15(2), 41-51. https://doi.org/10.1080/08923640109527083 
Madorin, S., \& Iwasiw, C. (1999). The effects of computer-assisted instruction on the selfefficacy of baccalaureate nursing students. Journal of Nursing Education, 38(6), 282-295.

McFarland, D.J., \& Hamilton, D. (2006). Adding contextual specificity to the technology acceptance model. Computers in Human Behavior, 22(3), 427-447. https://doi. org/10.1016/j.chb.2004.09.009

Ndubisi, N.O., \& Jantan, M. (2003). Evaluating IS usage in Malaysian small and mediumsized firms using the technology acceptance model. Logistics Information Management, 16(6), 440-450. https://doi.org/10.1108/09576050310503411

Nelson, D.L. (1990). Individual adjustment to information-driven technologies: A critical review. MIS Quarterly, 14(1), 79-98. https://doi.org/10.2307/249311

Ng, T.W.H. \& Sorensen, K.L. (2008). Towards a further understanding of the relationships between perceptions of support and work attitudes: A metaanalysis. Group \& Organization Management, 33(3), 243-268. https://doi. org/10.1177/1059601107313307

Noh, M., Kim, H., \& Jang, H. (2016). Learning performance and business performance of knowledge management organization: The moderating effect of technological capability. Information Development, 32(2), 1-18. https://doi. org $/ 10.1177 / 0266666914564629$

Oentoro, W., Popaitoon, P., \& Kongchan, A. (2016). Perceived supervisory support and service recovery performance: The moderating role of personality traits. Asia-Pacific Journal of Business Administration, 8(3),298-316. https://doi. org/10.1108/apjba-11-2015-0094

Ong, C.S., \& Lai, J.Y. (2006). Gender differences in perceptions and relationships among dominants of e-learning acceptance. Computers in Human Behavior, 22(5), 816829. https://doi.org/10.1016/j.chb.2004.03.006

Ong, C.S., Lay, J.Y., \& Wang, Y.S. (2004). Factors affecting engineers' adoption of asynchronous e-learning systems in high-tech companies. Information \& Management, 41(6), 795-804. https://doi.org/10.1016/j.im.2003.08.012

Park, N., Roman, R., Lee, S., \& Chung, J.E. (2009). User acceptance of a digital library system in developing countries: An application of the technology acceptance model. International Journal of Information Management, 29(3), 196-209. https://doi.org/10.1016/j.ijinfomgt.2008.07.001

Pastor, I.P., \& Perez, V.M. (2015). Does HRM generate ambidextrous employees for ambidextrous learning? The moderating role of management support. The International Journal of Human Resource Management, 26(5), 589-615. https://doi.org/10.1080/09585192.2014.938682

Piccoli, G., \& Ahmad, R. (2001). Web-based virtual learning environments: A research framework and a preliminary assessment of effectiveness in basic IT skills training. Blake Ives Source: MIS Quarterly, 25(4), 401-426. https://doi. org/10.2307/3250989

Purnomo, S.H., \& Lee, Y.H. (2012). E-learning adoption in the banking workplace in Indonesia: An empirical study. Information Development, 29(2), 138-153. https://doi.org/10.1177/0266666912448258 
Purvis, R.L., Sambamurthy, V., \& Zmud, R.W. (2001). The assimilation of knowledge platforms in organizations: An empirical investigation. Organization Science, 12(2), 117-135. https://doi.org/10.1287/orsc.12.2.117.10115

Roca, J.C., Chiu, C.M., \& Martínez, F.J. (2006). Understanding e-learning continuance intention: An extension of the technology acceptance model. International Journal of Human-Computer Studies, 64(8), 683-696. https://doi.org/10.1016/j. ijhcs.2006.01.003

Saade, R.G., \& Kira, D. (2009). Computer anxiety in e-learning: The effect of computer self-efficacy. Journal of Information Technology Education, 8(2009), 177-191. https://doi.org/10.28945/166

Setiawan, S.R.D. (2017). Tahun 2017, pengguna internet di Indonesia mencapai 143,26 juta orang. Retrieved 11 February 2019 from https://ekonomi.kompas.com/ $\mathrm{read} / 2018 / 02 / 19 / 161115126 /$ tahun-2017-pengguna-internet-di-indonesiamencapai-14326-juta-orang.

Sharma, R., \& Yetton, P. (2003). The contingent effects of management support and task interdependence on successful information systems implementation. MIS Quarterly, 27(4), 533-555. https://doi.org/10.2307/30036548

Stoner, J.A.F. (1995). Management (6th ed.). Englewood Cliffs, NJ: Prentice Hall, Inc.

Sun, H., \& Zhang, P. (2006). The role of moderating factors in user technology acceptance. International Journal of Human-Computer Studies, 64(2), 53-78. https://doi. org/10.1016/j.ijhcs.2005.04.013

Sun, P.C., Tsai, R.J., Finger, G., Chen, Y.Y., \& Yeh, D. (2008). What drives a successful e-learning? An empirical investigation of the critical factors influencing learner satisfaction. Computers and Education, 50(4), 1183-1202. https://doi. org/10.1016/j.compedu.2006.11.007

Tan, M., \& Teo, T.S.H. (2000). Factors influencing the adoption of internet banking. Journal of the Association for Information System, 1(5), 1-42.

Taylor, S., \& Todd, P.A. (1995). Assessing IT usage: The role of prior experience. MIS Quarterly, 19(4), 561-570. https://doi.org/10.2307/249633

Torkzadeh, G., \& Van Dyke, T.P. (2002). Effects of training on internet self-efficacy and computer user attitudes. Computers in Human Behavior, 18(5), 479-494. https://doi.org/10.1016/s0747-5632(02)00010-9

Tsai, C.C., \& Lin, C.C. (2004). Taiwanese adolescents' perceptions and attitudes regarding the internet: Exploring gender differences. Adolescence, 397(156), 725-734.

Tsai, M.J., \& Tsai, C.C. (2003). Information searching strategies in web-based science learning: The role of internet self-efficacy. Innovations in Education and Teaching International, 40(1), 43-50. https://doi.org/10.1080/1355800032000038822

Venkatesh, V. (1999). Creation of favorable user perceptions: Exploring the role intrinsic motivation. MIS Quarterly, 23(2), 239-260. https://doi.org/10.2307/249753

Venkatesh, V., \& Davis, F.D. (1996). A model of the antecedents of perceived ease of use: Development and test. Decision Sciences, 27(3), 451-481. https://doi. org/10.1111/j.1540-5915.1996.tb01822.x

Venkatesh, V., \& Davis, F.D. (2000). A theoretical extension of the technology acceptance model: Four longitudinal field studies. Management Science, 46(2), 186-204. https://doi.org/10.1287/mnsc.46.2.186.11926 
Venkatesh, V., \& Morris, M.G. (2000), Why don't men ever stop to ask for directions? Gender, social influence, and their role in technology acceptance and usage behavior. MIS Quarterly, 24(1), 115-139. https://doi.org/10.2307/3250981

Walker G.M. (2004). Faculty intentions to use web-enhanced instructional components. $\mathrm{PhD}$ dissertation, Capella University, USA.

Yeh, Y.C., Huang, L.Y., \& Yeh, L.Y. (2011). Knowledge management in blended learning: Effects on professional development in creativity instruction. Computers \& Education, 56(1), 146-156. https://doi.org/10.1016/j.compedu.2010.08.011 